\title{
Use of Web-based Portfolios to Assess the Technical Competencies of Engineering Technology Students: A Case Study
}

\author{
Sohail Anwar \\ The Pennsylvania State University, Altoona College \\ Jo-Ann Rolle and Altaf A. Memon \\ School of Business and Technology, Excelsior College
}

\begin{abstract}
On-line instruction is becoming a key component of numerous academic programs, largely as a result of the Internet and the proliferation of personal computers in offices and homes. Everyday, more and more educational institutions are introducing new online courses. Computer and telecommunication technological advances have provided alternatives to the traditional classroom setting.
\end{abstract}

The on-line learning environment facilitates a learner-centered approach to learning, with the learner as an active participant in the learning process. The approach requires that the teachers help learners to direct their own learning in ways that suit their individual learning styles.

This manuscript describes development and implementation of a Web CT-based course which requires the engineering technology students at Excelsior College to develop online portfolios reflecting technical competencies acquired by them during their academic studies. The course is titled "Integrated Technology Assessment" (ITA). It is a capstone experience for students documenting their ability to integrate knowledge from technology and general education areas and apply it in a meaningful way.

The manuscript provides a complete description of the ITA process at Excelsior College. Details regarding the use of information technology in creating the on-line learning environment for ITA students are also presented.

Introduction

Distance learning provides excellent opportunities for students to acquire academic degrees from educational institutions while working at remote locations ${ }^{1}$. Although not 
yet "mainstream", on-line courses delivered over the Internet are becoming more common $^{2}$. Educational institutions at all levels are looking at this form of delivery in the context of the future learning needs of their students. There are many advantages of online learning. It is borderless and is a practical way of learning for those who cannot travel to attend classes at an educational institution. It is flexible and allows students to learn at their own pace.

\section{Background}

Excelsior College with approximately 27,000 enrolled students, is one of the most respected distance learning institution in higher education. Founded in 1971 by the New York State Board of Regents as its external degree program and known in earlier years as Regents College, it was granted an independent charter in 1998. It changed its name to Excelsior College in 2001.

Always at the forefront of distance learning, Excelsior College has initiated several innovative programs in cooperation with business, industry, the military, and other academic institutions. The College introduced new academic programs incorporating industry-standard training received while on the job in fields as diverse as risk management and insurance, criminal justice, and nuclear engineering technology. To enable its students, all of whom are studying at a distance, to have online access to library facilities, the Excelsior College Virtual Library was introduced in 2000. In cooperation with the Sheridan Libraries at The Johns Hopkins University, Excelsior's students have access to the collection and services of one of America's most prestigious and extensive libraries.

Excelsior College made its first venture into instruction at-a-distance with the introduction of its Master of Arts in Liberal Studies (1998) and Master of Science in nursing (1999) programs. Using the experience gained in these, the College has recently made a successful transition into the delivery of instruction in its undergraduate programs and now offers more than 100 courses at this level.

Excelsior College has been continuously accredited by the Commission on Higher Education of the Middle States Association of Colleges and Schools since 1977. Recognizing that college-level knowledge can be obtained in many ways, Excelsior provides access to many different avenues for earning college credit, focusing on what students know, rather than on where or how they learned it. Undergraduate credits are earned through a variety of accredited sources including for-credit exams, distance learning and online courses offered by Excelsior and other institutions; traditional campus-based courses; and military and corporate training. Excelsior's graduate degrees are delivered online. Through these means, the college makes associate, baccalaureate, and master's degrees more accessible to busy, working adults.

Excelsior's associate, bachelor's and master's degree programs in nursing are accredited by the National League for Nursing Accrediting Commission. Its Bachelor of Science degrees in Electronics Engineering Technology and Nuclear Engineering Technology are 
accredited by the Technology Accreditation Commission of the Accreditation Board for Engineering and Technology. The American Council on Education (ACE) recognizes all Excelsior College Examinations for the award of college-level credit.

\section{The BS-Electronics Engineering Technology Program of Excelsior College}

The ABET-accredited BS in Electronics Engineering Technology degree program offered by Excelsior College requires 124 semester hours of credits, including at least 60 credits in the arts and sciences component and at least 48 credits in the electronics engineering technology component. All the BS-Electronics Engineering Technology students must complete at least one course or examination in each of the following subjects constituting the Electronics Engineering Technology core requirements.

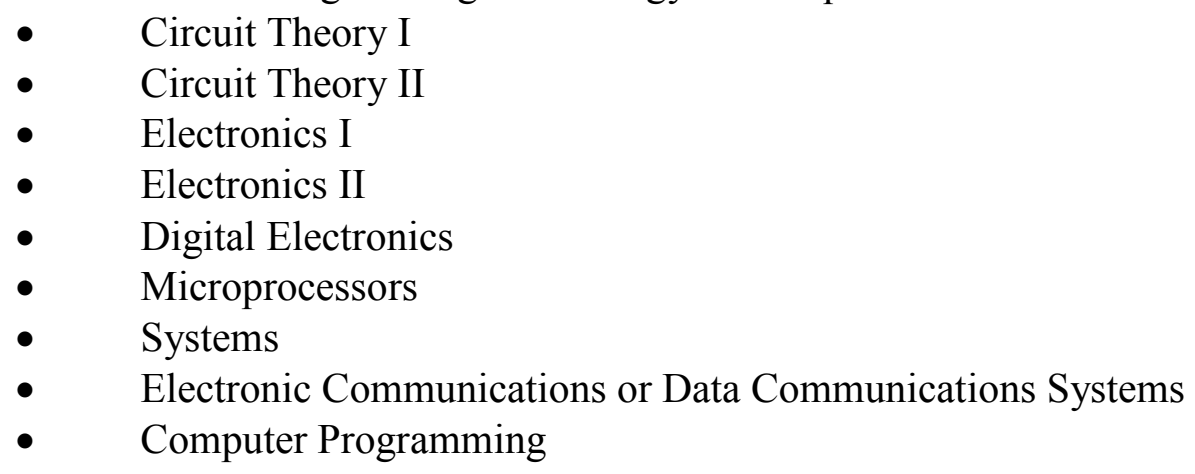

In addition to the Electronics Engineering Technology core requirements, students must complete a 3-credit Integrated Technology Assessment (ITA) requirement.

An Overview of the Integrated Technology Assessment (ITA) Process

Every student enrolled in the BS-Electronics Engineering Technology program at Excelsior College is required to participate in the ITA development process by taking a senior-level course labeled ELEC 495.

Every student who enrolls in ELEC 495 is assigned a faculty mentor. The entire course process consists of a 15-week timeline. The first four weeks consist of a WebCT selfpaced asynchronous portfolio development process resulting in a professional resume and an ITA plan/outline. Weekly assignments for students during the first four weeks are as follows:

- Week 1 - Review course policies and procedures

- Develop professional resume

- Week 2 - Develop ITA plan/outline

- Week 3 - Develop draft learning statements for ITA objectives 1-5

- Week 4 - Develop draft learning statements for ITA objectives 6-9

Faculty mentor is required to review and provide feedback on professional resume during week 2, on the ITA plan/outline during week 3, on draft learning statements for 
ITA objectives 1-5 during week 4, and on draft learning statements for ITA objectives 69 during week 5 .

During the remainder of timeline for ELEC 495, following activities take place:

- Weeks 5 through 12 - Student completion of ITA

- Week thirteen - Faculty mentor review of complete ITA document

- Week fourteen - Student revision, if necessary

- Week fifteen - Final grading by faculty mentor

\section{ITA Objectives}

Students enrolled in the BS-Electronics Engineering Technology program are required to address thirteen ITA learning objectives. These objectives are listed in TABLE 1.

\section{TABLE 1: BS-ELECTRONICS ENGINEERING TECHNOLOGY ITA LEARNING OBJECTIVES}

\begin{tabular}{|c|c|}
\hline Objective Number & An electronic engineering technology graduate will be able to: \\
\hline 1 & Demonstrate a fundamental knowledge of natural sciences, including physics. \\
\hline 2 & $\begin{array}{l}\text { Demonstrate the ability to measure, and provide quantitative expressions of natural science } \\
\text { phenomena, including experimentation, observation, and accurate measurement. }\end{array}$ \\
\hline 3 & $\begin{array}{l}\text { Apply the fundamentals of algebra, trigonometry, and calculus to problem solving in the } \\
\text { electronics engineering technology area. }\end{array}$ \\
\hline & Make technical presentations in English using language appropriate to the audience. \\
\hline 5 & $\begin{array}{l}\text { Demonstrate proficiency in the written communication of technical information using } \\
\text { standard English. }\end{array}$ \\
\hline 6 & $\begin{array}{l}\text { Demonstrate a working knowledge of computer usage including knowledge of one or more } \\
\text { computer languages and documentation of the use of one or more computer software } \\
\text { packages for technical problem solving appropriate to the electronics engineering technology } \\
\text { discipline. }\end{array}$ \\
\hline 7 & $\begin{array}{l}\text { Demonstrate technical competency in electronics, circuit analysis, digital electronics, } \\
\text { electronic communications, microprocessors, and systems. }\end{array}$ \\
\hline & Integrate knowledge of the functional areas of electronics engineering technology. \\
\hline 9 & $\begin{array}{l}\text { Demonstrate the ability to analyze, apply design concepts, and implement systems as } \\
\text { appropriate to electronics engineering technology. }\end{array}$ \\
\hline 10 & $\begin{array}{l}\text { Participate effectively in groups, and apply project management techniques as appropriate to } \\
\text { complete assignments. }\end{array}$ \\
\hline 11 & $\begin{array}{l}\text { Demonstrate an ability to understand professional, ethical and social responsibilities, } \\
\text { including the impacts of culture, diversity, and interpersonal relations. }\end{array}$ \\
\hline 12 & Demonstrate a commitment and ability to continue to engage in lifelong learning. \\
\hline 13 & Demonstrate a commitment to quality, timeliness, and continuous improvement. \\
\hline
\end{tabular}

\section{ITA Learning Statements}


Students enrolled in ELEC 495 (or NUC 495) are required to develop learning statements that objectively address the ITA learning objectives. A learning statement must include an explanation and example(s) of how a given learning objective has been met. Evidence must be provided in support of every learning statement. The relationship between the given learning objective and the corresponding evidence must be explained. The essential elements of good learning statements are as follows:

- Written clearly and concisely in Standard Written English

- Written in the form of a narrative

- $\quad$ Supporting evidence is referenced and provided

- $\quad$ Describe how the evidence supports the learning statement

- Show how the learning statements relate directly to the objectives

- $\quad$ Address each of the characteristics of the objectives in full

The essential elements of good sources of evidence are as follows:

- $\quad$ Legible

- $\quad$ Clearly labeled and referenced in text

- $\quad$ Relevant to the learning statement

- $\quad$ Supportive of the learning statement

- $\quad$ Letters from supervisors or other individuals should include contact information (if possible)

- $\quad$ Letters should be written on official letterhead (if possible) follows:

Sample learning statements and evidence that can be used to support them are as Learning Objective 1 - Demonstrate a fundamental knowledge of natural sciences, including physics.

Characteristics:

Recognize the connections between the knowledge of natural sciences and your discipline, job, hobby, or courses completed later Identify the specific scientific principles used

\section{Sample Learning Statements:}

- $\quad$ As a Field Engineer at ACME Company, I need to have a good comprehension of natural sciences and physics to understand, troubleshoot, and teach others how the given equipment is designed to function and if it is not functioning as designed, explain why the equipment is performing differently. I am attaching copies of several failure reports that describe the problems and their resolution.

- I studied the principle of harmonics in the General Physics course at University College and later applied that concept to the creation and application of band-pass and band-stop filters in the Networks 133 course at University College. Attached are several examples of my coursework. 
- I studied the principle of solid state and atomic theory in the General Physics course at University College and later applied that concept in the study of $\mathrm{P}$ and $\mathrm{N}$ materials in the solid-state electronics course at University College. Attached are several examples of my coursework.

- In my job, I perform tests and performance evaluations on aircraft navigation, communications, and sensor systems. These systems measure natural phenomena to complete their mission. The physics and chemistry classes that I took at University College provided a strong background, coupled with years of technical experience, and have significantly contributed to my ability to solve difficult technical problems. Copies of my last two performance reviews are included.

- As an instructor at State Technical Institute, I teach the principles of physics in various courses. As Evidence of this, I am including copies of my syllabus and lecture notes.

- In my position as Engineering Technical Support at ACME Company, I needed to have the knowledge of heat and thermal energy, and the thermal properties of matter to conduct and perform efficiency measurements of engines. Attached is a copy of the test procedure and sample results.

- In my hobby of sailing, I must understand the interaction between the wind and the sail. As I sail the boat, I calculate these factors using the principles of mechanics including vector algebra. I am including sample calculations.

Technology Requirements for ELEC 493

The technology requirements for ELEC 495 are listed in TABLE 2 
TABLE 2: TECHNOLOGY REQUIREMENTS

\begin{tabular}{|c|c|c|}
\hline $\begin{array}{l}\text { ALL USERS } \\
\text { Monitor }\end{array}$ & $\begin{array}{l}\text { Minimum } \\
15 \text { " VGA } \\
256 \text { colors } \\
800 X 600 \\
\text { resolution }\end{array}$ & $\begin{array}{l}\text { Recommended } \\
17 \text { "SVGA } \\
\text { True color } \\
1024 \times 768 \\
\text { resolution }\end{array}$ \\
\hline $\begin{array}{l}\text { Internet } \\
\text { Connection }\end{array}$ & $56 \mathrm{~K}$ modem & $\begin{array}{l}\text { Broadband (cable } \\
\text { or DCL) }\end{array}$ \\
\hline Email Capabilities & $\begin{array}{l}\text { Unique email } \\
\text { address } \\
\text { (not shared by } \\
\text { family members } \\
\text { or friends) }\end{array}$ & $\begin{array}{l}\text { Unique email } \\
\text { address }\end{array}$ \\
\hline $\begin{array}{l}\text { Plugins } \\
\text { Peripherals }\end{array}$ & $\begin{array}{l}\text { Adobe Acrobat } \\
\text { Reader } 5 \\
\text { Video card } \\
\text { capable of } \\
800 X 600 \text { pixel } \\
\text { resolution }\end{array}$ & $\begin{array}{l}\text { Adobe Acrobat } \\
\text { Reader } 6 \\
\text { Video card } \\
\text { capable of } \\
1024 \times 768 \text { pixel } \\
\text { resolution }\end{array}$ \\
\hline $\begin{array}{l}\text { PC USERS } \\
\text { Processor }\end{array}$ & $\begin{array}{l}\text { Minimum } \\
\text { Pentium } 233 \mathrm{MHz}\end{array}$ & $\begin{array}{l}\text { Recommended } \\
\text { Pentium } 733 \\
\text { MHz }\end{array}$ \\
\hline $\begin{array}{l}\text { RAM } \\
\text { Browser } \\
\text { (only one needed) }\end{array}$ & $\begin{array}{l}64 \mathrm{MB} \\
\text { MS Internet } \\
\text { Explorer 5.5 } \\
\text { Netscape } 7.0\end{array}$ & $\begin{array}{l}128 \mathrm{MB} \\
\text { MS Internet } \\
\text { Explorer } 6.0 \\
\text { Netscape } 7.1\end{array}$ \\
\hline $\begin{array}{l}\text { MACINTOSH } \\
\text { USERS } \\
\text { Processor }\end{array}$ & $\begin{array}{l}\text { Minimum } \\
233 \mathrm{MHz}\end{array}$ & $\begin{array}{l}\text { Recommended } \\
\text { G3 }\end{array}$ \\
\hline $\begin{array}{l}\text { RAM } \\
\text { Browser } \\
\text { (only one needed) }\end{array}$ & $\begin{array}{l}64 \mathrm{MB} \\
\text { MS Internet } \\
\text { Explorer 5.1 } \\
\text { Netscape } 7.0\end{array}$ & $\begin{array}{l}128 \mathrm{MB} \\
\text { MS Internet } \\
\text { Explorer } 5.2 \\
\text { Netscape } 7.1\end{array}$ \\
\hline
\end{tabular}




\section{Students' Competencies}

When students take courses on-line, there re assumptions that students will have a basic knowledge of computer hardware and software. Specifically, students taking ELEC 495 are expected to have:

- Knowledge of computer terminology;

- Knowledge of computer hardware;

- Skill in electronic communication;

- Ability to prepare a word processing document;

- Ability to prepare a word processing document;

- Ability to navigate the Internet;

- Working knowledge of database and spread sheet software;

- Ability to evaluate information presented on a web site;

- Ability to search the literature using an on-line database.

Role of the Faculty Mentor

The role of ITA faculty mentor is to:

- Review and comment on the student's professional resume during the first two weeks of the course

- Review and approve the student's ITA plan during the third week of the course

- Review and provide feedback on draft learning statements 1-9 during weeks four and five

- Review and comment on drafts of learning statements and evidence submitted during weeks five through twelve

- Provide feedback on all materials submitted by student

- Grade ITA according to established procedures/deadlines and scoring rubric

- Stay in touch with student during the semester by phone, fax, WebCT, and/or email The student is expected to establish and maintain a professional relationship with the faculty mentor. The two should maintain contact with each other throughout the semester. The student will provide the mentor with a current telephone number, email address, and fax number (if deemed necessary). The faculty mentor will provide appropriate contact information to the student. A student who does not submit materials according to schedule, or does not maintain communications with the mentor, risks failure in the course.

\section{ITA Grading}

ITA students submit all the ITA materials via WebCT, e-mail, and/or computer disk. The professional resume, ITA plan/outline, and learning statements should be in Word format. Evidence may also be in Word files or may be scanned onto a CD-ROM. The completed ITA must be submitted by the end of week twelve. Upon review, the faculty mentor may require the student to resubmit a section or sections. The resubmission/final draft of ITA must be submitted by the end of week fourteen. 
The following scoring rubric is used by the ITA faculty mentor to grade student's response to each of the ITA learning objectives:

NS - No Submission

NR - Not Responsive

MR - Minimally Responsive

$\mathrm{R}$ - Responsive

HR - Highly Responsive

Each of these ratings has a specific meaning (competency statement) associated with it according to the learning objective to be evaluated. For example, for the Electronics Engineering Technology ITA Objective 1, the competency statements associated with the scoring rubric are as follows:

TABLE 3: SCORING RUBRICS FOR ITA

\begin{tabular}{|c|l|l|}
\hline $\begin{array}{c}\text { Rating } \\
\text { Scale }\end{array}$ & \multicolumn{1}{|c|}{$\begin{array}{c}\text { Rating } \\
\text { Definition }\end{array}$} & $\begin{array}{c}\text { Electronics Engineering Technology Objectives 1 } \\
\text { Competency Statements }\end{array}$ \\
\hline NS & No Submission & $\begin{array}{l}\text { Evidence not provided for relevant courses. } \\
\text { Responsive } \\
\text { Coursework and other examples not demonstrative of } \\
\text { required knowledge }\end{array}$ \\
\hline NR & $\begin{array}{l}\text { Minimally } \\
\text { Responsive }\end{array}$ & $\begin{array}{l}\text { Presents appropriate course evidence with a few } \\
\text { examples from coursework and a few connections } \\
\text { between coursework and applications }\end{array}$ \\
\hline R & Responsive & $\begin{array}{l}\text { As in MR above and presents multiple examples of } \\
\text { coursework and clear evidence of applications to the } \\
\text { discipline, job, hobby, or later courses }\end{array}$ \\
\hline HR & $\begin{array}{l}\text { Highly } \\
\text { Responsive }\end{array}$ & $\begin{array}{l}\text { As in R above and presents many detailed examples } \\
\text { of coursework and applications in career or other } \\
\text { activities }\end{array}$ \\
\hline
\end{tabular}

\section{ELEC 495 Course Evaluation}

A course evaluation template is provided to students in each on-line course for course evaluation. The template consists of 27 questions. Twenty four of these questions employ a rating scale ranging from 1 to 7 . A rating of 1 denotes "strongly disagree" while a rating of 7 represents "strongly agree". The remaining three questions solicit a subjective response from students. All the twenty seven questions are listed below:

1. The grading policy was made clear at the beginning of the course.

2. Initial instructions did not clarify the course objectives and content at the beginning of the course.

3. Interacting with other students helped me meet the learning objectives of this course. 
4. Engaging with other students in course related activities (e.g., discussions, team projects, etc.) made me feel like I was part of a learning community.

5. The instructor did an excellent job interacting with students using available technology (e.g., email, discussion boards, chat).

6. I understood what I needed to do to complete my assignments.

7. Graded assignments were not related to the course objectives.

8. Assignments stimulated my interest in the topics covered in this course.

9. Graded assignments for this course were returned quickly.

10. The time given to complete assignments allowed me to do my best work.

11. The discussion questions did not help me learn the content of the course.

12. The feedback I received on my assignments from this course helped me perform better on subsequent assignments.

13. The readings for this course were not presented in a logical order.

14. The readings for this course stimulated new thinking about course content.

15. The readings for this course helped me meet the learning objectives of the course.

16. The instructor conducted this course in a way that accomplished the stated objectives.

17. The instructor for this course responded to questions in a timely manner.

18. The instructor for this course did not seem interested in helping me learn the material.

19. The instructor's feedback helped me learn.

20. The course schedule was not flexible enough to meet my needs.

21. I would recommend this course to others.

22. Overall I was very satisfied with this course.

23. Before starting my online course(s) I received sufficient information about registration requirements and prerequisites.

24. Before starting my online course(s) I received sufficient information about student support services.

25. WebCT is the name of the software program used to administer this course. Did you have any problems using WebCT that you would like to share? If yes, what were they?

26. If you felt this course faired poorly on any of the above dimensions (or any that were not included above), what could we change to improve the course?

27. Do you have any additional comments you would like to share with us?

\section{Conclusion}

This manuscript described development and implementation of a comprehensive assessment method used by Excelsior College to assess the skills acquired by students enrolled in the BS-Electronics Engineering Technology and BS-Nuclear Engineering Technology programs offered by the College. This assessment method known as The Integrated Technology Assessment (ITA), requires that learners (students) take an active part in the learning process and participate by formulating initial ideas, considering faculty mentor's responses, and reflecting on ideas in the light of contribution to the discussions with faculty mentor. In this way, learners go through a cognitive process whereby thoughts and ideas are refined and adapted taking into consideration other views 
and perspectives of the original concept. The ITA students experience ITA development process is a transforming process which leads to greater personal understanding. The Excelsior college Industrial Advisory Committees (Electronics Engineering Technology and Nuclear Engineering Technology) which consist of industrial representatives and practicing engineers fully participate in the annual review of ITA policies and procedures.

Bibliography

1. Kandasamy, S., and Manian, R. "Distance Delivery of a Laboratory Based Controls for Manufacturing Automation Course - A Success Story", Proceedings of the $34^{\text {th }}$ ASEE/IEEE Frontiers in Education Conference, October 20-23, 2004. Available CD-ROM

2. Lawrence-Slater, M. "On-line Learning: A Student Viewpoint", Proceedings of the $32^{\text {nd }}$ ASEE/IEEE Frontiers in Education Conference, November 6-9, 2002. Available CD-ROM

Biography

SOHAIL ANWAR

Sohail Anwar holds a Ph.D. degree in Industrial and Vocational Education from the Pennsylvania State University and a M.S. degree in Electrical Engineering from the University of Texas at Arlington. He completed additional graduate coursework in control theory and applied mathematical sciences at the University of Texas at Arlington. He is currently serving as an associate professor of Engineering and the Program Coordinator of Electrical Engineering Technology at The Pennsylvania State University, Altoona College. Since 1996, he has also served as an invited professor of Electrical Engineering at IUT Bethune, France.

JO-ANN ROLLE

Jo-Ann Rolle holds a Ph.D. degree in Economics from the Howard University and a M.A. degree in Economics from the Southern Illinois University, Edwardsville. She is currently serving as the Dean of the School of Business and Technology at the Excelsior College, Albany, New York.

\section{ALTAF A. MEMON}

Altaf Memon holds MSCE, MPW, and Ph.D. degrees from the University of Pittsburgh, Pittsburgh, Pennsylvania and an M.Eng. degree in Environmental Engineering from the Asian Institute of Technology, Bangkok. He is currently serving as the Associate Dean of the School of Business and Technology at the Excelsior College, Albany, New York. 